\title{
INFLUENCE OF THE HIGHLY PATHOGENIC AVIAN INFLUENZA OUTBREAK OF 2016 ON POULTRY MEAT CONSUMPTION
}

\author{
L. BognÁR ${ }^{a *}$, P. MiKULKA ${ }^{b}$ and Gy. KasZA ${ }^{b}$ \\ ${ }^{a}$ Ministry of Agriculture, H-1055 Budapest, Kossuth Lajos tér 11. Hungary

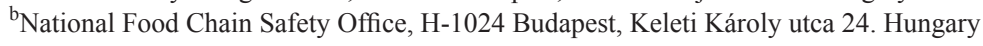

(Received: 12 February 2018; accepted: 21 April 2018)

\begin{abstract}
Between November 2016 and April 2017, 240 H5N8 outbreaks of highly pathogenic avian influenza have been registered in Hungary resulting in the culling of 3.45 million poultry. Aiming at the prevention of the reoccurrence of the public scare experienced in regard of the H5N1 outbreak in 2006, in 2016 a more proactive and responsive communication activity has been implemented, which resulted in a total of 1661 media appearances. For consistent and credible information, all press inquiries were answered by the Chief Veterinary Officer of Hungary, and journalists received the requested information usually within 8 hours. In order to understand how effective communication methods help to stop decrease of poultry meat consumption, determinative factors according to consumer risk perception and changes in poultry meat consumption were identified. Analysis of the consumer survey conducted in 2016 showed that education and gender were the most important socio-demographic variables, though poultry consumption was almost completely undisturbed. The results of the 2016 consumer survey were compared to a corresponding dataset published on the 2006 avian influenza public scare, which showed $12.6 \%$ increase in the number of those respondents, who have not changed their consumption behaviour due to avian influenza.
\end{abstract}

Keywords: food safety, avian influenza, risk perception, consumer behaviour, consumer survey

Food safety, in spite of the continuous development in field of science, technology, and legislation, is still one of the most fundamental challenges of our time. Food-borne diseases affect $10-30 \%$ of the population even in developed countries every year, and the majority of food-related illnesses derive from zoonotic infections (SzEITZ-SzABÓ \& FARKAS, 2004; LACZAY, 2012). The written records of influenza epidemics date back to the $16^{\text {th }}$ century, and since then, usually 2-3 epidemics occur per century (WHO, 2003). The 3 most serious epidemics ('Spanish flu', 'Asian influenza', 'Hong Kong influenza') that were documented in the $20^{\text {th }}$ century, causing the death of millions of people (WHO, 2009), have been reported to have genes adapted from avian strains. LYCETT and co-workers (2016) have proven that long-distance migratory birds could play the major role in the global spread of avian influenza viruses.

In Hungary, the first outbreaks of H5N1 occurred in February 2006, primarily affecting wild birds. The virus temporarily disappeared, but unexpectedly re-emerged in June 2006, and resulted in the largest domestic waterfowl epizootic event in Europe (SzELECZKY et al., 2009). Ten years later, in November 2016, the appearance of another highly pathogenic avian influenza strain (H5N8) was registered in the country, with the emergence of 240 outbreaks. In their recent study, BRown and co-workers (2017) concluded that the (H5N8) highly pathogenic avian influenza epidemic occurred in 29 European countries and has been the

\footnotetext{
* To whom correspondence should be addressed.

Phone: +36 20454 8418; e-mail: kaszagy@nehib.gov.hu
} 
largest ever recorded in the EU in terms of number of outbreaks (over 2600 in wild birds, poultry and captive birds), geographical extent, and number of dead wild birds. They add that despite a large extent of human exposure to infected poultry, no transmission to humans has been identified. In Hungary, the last case was confirmed in 24 ${ }^{\text {th }}$ April 2017.

Based on the most recent data of the Hungarian Central Statistical Office (HCSO, 2016), poultry meat still accounts for $44.9 \%$ of the total meat consumption in Hungary, and despite the economic crisis that we had to deal with in the first decade of the $21^{\text {th }}$ century, the demand for poultry meat is still expanding steadily (ÓzSvÁRI et al., 2017). According to SIEGRIST and Cvetkovich (2000) and Verbeke and co-workers (2007), the propensity of consumers to overestimate some risks relative to the probability of harm occurring is commonly high, which explains the difference between the perceived risk and actual risk of avian influenza epidemic. FREWER (2004) argues that even though public concerns might seem irrational to policy makers, the psychological factors that contribute to these concerns should be taken into account during risk communication. Considering this approach and the mechanism of risk perception as explained by FischHoff and co-workers (1978) and Slovic and Peters (2006), information provision should be timely, credible, operating with clear messages, and also should address uncertainties in order to prevent or mitigate public outrages deriving from risk perception bias. Based on these theoretical considerations, in 2016 the National Food Chain Safety Office (NFCSO) has adopted a crisis communication scheme that aimed to pursue a proactive and responsive communication activity to prevent possible damage caused by communication vacuum or untreated elements of public distrust. For consistent and credible information provision, all press inquiries were responded by the Chief Veterinary Officer of Hungary, and journalists received the requested information usually within 8 but maximum 24 hours. More than 240 interview inquiries were received, and $65 \%$ of these required verbal interview (television or radio). Beside the inquiries, 15 original articles were published by NFCSO, with a reach of 4 million people in average. During the period of H5N8 outbreaks, a total of 1661 media appearances were recorded. According to NFCSO's own estimation, similar media coverage would require a budget of about 1 million euro for a commercial communication campaign in Hungary. A special avian influenza section was also created on the NFCSO's website offering actual news on the outbreaks, trade restrictions, fact sheets for consumers, and information materials for farmers. This webpage has recorded more than 27000 individual visitors. After the experiences of the first month, decision was made to intensify the communication at county and district levels, where people faced the risks of avian influenza closely. The Chief Veterinary Officer personally consulted with the mayors of the affected settlements, and as a result, 200000 leaflets were printed and distributed to local civilians (especially focusing on those who kept animals) and the personnel of public services. To draw farmers' attention to the syndromes, the course of illness, and also the means of prevention, 34000 detailed information materials were printed and distributed. The most important messages also appeared on more than 2000 posters at the most frequented locations.

We have a report on the risk perception outcomes of the H5N1 outbreaks from 2006 (KASZA \& LAKNER, 2006). According to the results of this study, 24\% of the consumers decreased their poultry meat consumption significantly. In this paper, we present the results of a consumer survey conducted in 2016 after the H5N8 outbreaks in Hungary and compare them to the findings from 2006 . We endeavour to point out that appropriate risk communication methods are capable of effectively minimizing poultry meat consumption decrease. However, some limitations of the direct comparison must be noted. First of all, the changes in consumer 
prices during the two crisis situations show remarkable differences (Fig. 1). Fall of the prices could be observed in both cases, but the drop was considerably stronger in 2016. Secondly, general changes in socio-demographic variables of the population between the two periods may also have an impact on the reactions.

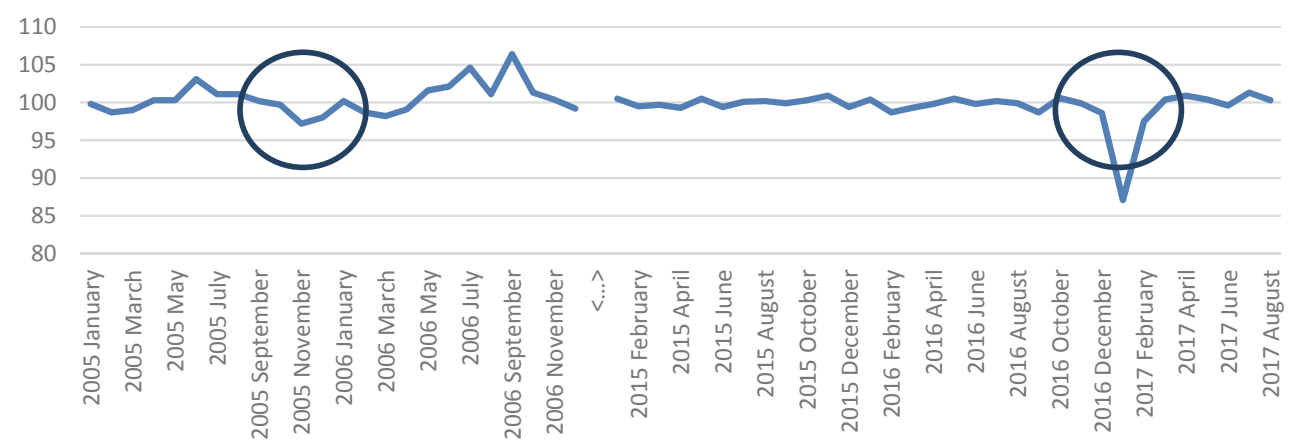

Fig. 1. Changes of the consumer price index of poultry meat during the avian influenza outbreaks in 2005-2006 and 2016-2017 (last month $=100.0 \%$ ) (Data source: HCSO, 2018)

\section{Materials and methods}

\subsection{Research methodology}

The research methodology was a questionnaire-based quantitative consumer survey. The sample was taken through voluntary personal interviews, during which a total of 1000 valid questionnaires were received. Participants were recruited from November to December of 2016 at 8 separate locations of Hungary: Budapest, Debrecen, Győr, Miskolc, Nyíregyháza, Szeged, Pécs, and Veszprém. At the beginning, all pedestrians were approached at the selected public locations, but in the later phases of the survey, the potential participants were filtered according to the gender, age, and habitation quotas.

\subsection{Sample characteristics}

Data were collected from a total of 1000 respondents during the survey, which provided adequate basis for carrying out reliable statistical analyses. The sample was representative for gender (female: $53.60 \%$, male: $46.40 \%$ ), age (18-30: 16.70\%, 30-39: 18.70\%, 40-59: $35.00 \%$, over 60: $29.60 \%$ ), and geographical regions, pro rata in regard of the country's seven planning-statistical NUTS 2 regions (Central Hungary: 28.30\%, Central Transdanubia: 11.20\%, Western Transdanubia: 10.90\%, Southern Transdanubia: 8.40\%, Northern Hungary: $12.60 \%$, Northern Plain: $15.60 \%$, Southern Plain: $13.00 \%$ ). Representativity was assured by fitting the sample composition to the 2011 census data of the Hungarian Central Statistical Office that has been adjusted by a micro-census in 2014 (HCSO, 2014).

\subsection{Statistical analysis}

The data was analysed with the IBM SPSS Statistics 22.0 software package, which was specifically designed for social science statistics. The analysis started with descriptive statistical tools, which allowed the general overview of the results and the understanding of 
simple relationships. To specify the main determining factors of consumer behaviour, Chisquare Automatic Interaction Detection (CHAID) classification tree modelling technique was used. The CHAID method evaluates complex interactions of the predictor variables and the dependent variable, and displays the modelling results in an easy-to-interpret tree diagram (HÁmoRI, 2001). Significant results were also investigated with cross-tables and $\mathrm{Chi}^{2}$-test, using the Pearson method. The confidence interval was $95 \%$, as it is commonly used in social sciences.

\section{Results and discussion}

\subsection{Determination and characterization of the most decisive factors of consumer risk perception regarding poultry meat consumption}

Of the respondents, $82.58 \%$ have heard about the 2016 avian influenza epidemic. Only their answers were analysed. In order to determine which factors mainly influence consumer risk perceptions in case of avian influenza, we used CHAID exploratory data analysis method. The dependent variable was 'The change of poultry meat consumption due to avian influenza outbreaks' and the possible predictor variables were demographic (gender, age, habitation) and social (education, social status, income level) attributions. The method required the omission of irrelevant or inappropriate responses, which resulted in 772 adequate answers. Results are presented in Figure 2 in a tree diagram, which clearly indicates the complex interactions of the 2 predictors and the dependent variable.

Based on the findings, education was the most decisive factor of consumer risk perception regarding poultry meat consumption during the 2016 avian influenza epidemic. Significant difference $(\mathrm{P}=0.014)$ was found between respondents with lower (elementary/ vocational school) and higher (high school/higher education) qualifications. Of respondents with lower education level, $7.2 \%$ stated that they have not eaten poultry meat since the outbreak, while in case of higher educated participants this proportion was only $1.9 \%$. It is also important that $15.7 \%$ of lower educated respondents eat much less poultry meat since the epidemic, while considering the higher educated participants, this rate is only $8.6 \%$. Of the respondents with lower qualifications, $22.9 \%$ changed their poultry consumption patterns due to the avian influenza outbreak of 2016. This result is in accordance with the previous study of WILDAVSKY and DAKE (1990), which indicated that lower knowledge level leads to less realistic public perceptions. The risk perception of persons having secondary or higher education was further strongly influenced by gender $(\mathrm{P}=0.041)$. Compared to male respondents, females have been proven to be more cautious regarding poultry consumption. This result is consistent with previous studies (FLYNN et al., 1994; BYrNES et al., 1999; BÁNÁTI \& LAKNER, 2002; Charness \& GNEezy, 2012) that found females' propensity to overestimate risk to be significantly higher than males'.

The further analysis of significant results was managed with cross-tables and $\mathrm{Chi}^{2}$-test, using the Pearson method. The relationship between education level and changes in poultry meat consumption due to the avian influenza outbreak is presented in detail in Table 1, which clearly illustrates that the ratio of participants who are abandoned or reduced poultry meat consumption is inversely related to the degree of education. While the chicken meat consumption frequency was unchanged in $89.00 \%$ for those with higher education, this ratio was only $66.7 \%$ for participants with primary education, and $80.6 \%$ for vocational qualifications. 


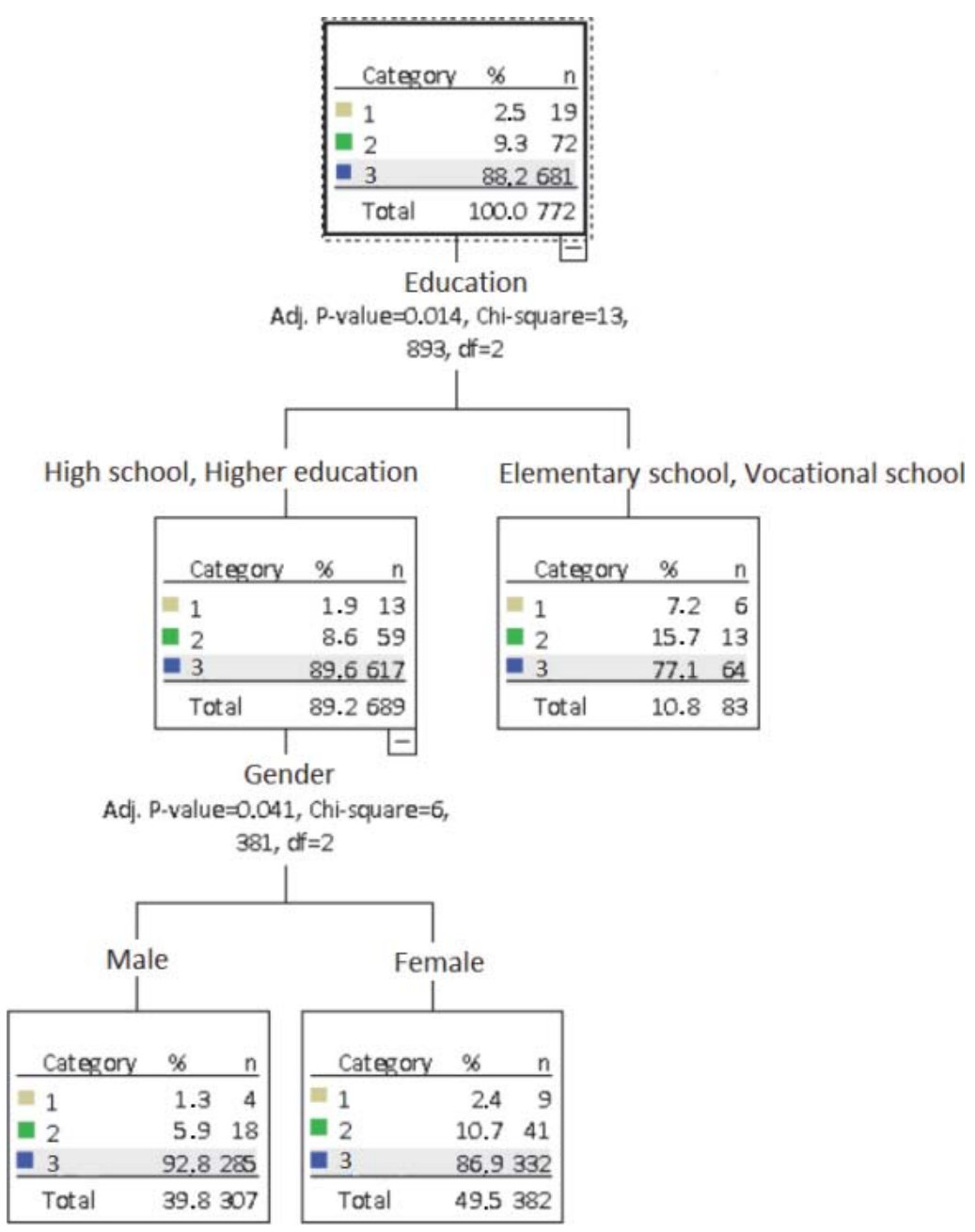

Fig. 2. Main socio-demographic variables influencing consumer risk perception regarding avian influenza scandal in 2016 (1: Have not eaten poultry meat due to the avian flu outbreak; 2: Eat much less poultry meat due to the avian flu outbreak; 3: Have not changed the consumption behaviour)

Table 1. Changes in poultry meat consumption habits according to the education level (\%)

\begin{tabular}{|c|c|c|c|c|c|}
\hline & $\begin{array}{c}\text { Elementary } \\
\text { school }\end{array}$ & $\begin{array}{l}\text { Vocational } \\
\text { school }\end{array}$ & $\begin{array}{l}\text { High } \\
\text { school }\end{array}$ & $\begin{array}{l}\text { Higher } \\
\text { education }\end{array}$ & Total \\
\hline $\begin{array}{l}\text { Abandoned or significantly reduced poultry } \\
\text { meat consumption }\end{array}$ & 14.3 & 4.8 & 1.7 & 2.1 & 2.5 \\
\hline Reduced poultry meat consumption & 19.0 & 14.6 & 8.3 & 8.7 & 9.3 \\
\hline Unchanged poultry meat consumption & 66.7 & 80.6 & 90.0 & 89.2 & 88.2 \\
\hline Total & 100.0 & 100.0 & 100.0 & 100.0 & 100.0 \\
\hline
\end{tabular}


The level of income was also found to have an impact on the change of consumption patterns. According to the results demonstrated in Table 2, the percentage of those whose poultry meat consumption remained unchanged was significantly higher among consumers with higher income level. Consequently, the number of respondents who abandoned or reduced poultry meat consumption were found in a higher share among participants with low income level. This result is in accordance with the previous study of SLIMAK and DIETZ (2006). They also assumed that income and education are probably interrelated variables, thus higher levels of income are most often associated with higher levels of education.

Table 2. Changes in poultry meat consumption habits according to the income level (\%)

\begin{tabular}{lccrr}
\hline & $\begin{array}{c}\text { Low income } \\
\text { level }\end{array}$ & $\begin{array}{c}\text { Medium } \\
\text { income level }\end{array}$ & $\begin{array}{c}\text { High income } \\
\text { level }\end{array}$ & Total \\
\hline $\begin{array}{l}\text { Abandoned or significantly reduced poultry meat } \\
\text { consumption }\end{array}$ & 5.2 & 1.9 & 1.0 & 2.5 \\
Reduced poultry meat consumption & 10.5 & 9.6 & 5.9 & 9.2 \\
Unchanged poultry meat consumption & 84.3 & 88.5 & 93.1 & 88.3 \\
Total & 100.0 & 100.0 & 100.0 & 100.0 \\
\hline
\end{tabular}

\subsection{Comparison of the impact of the 2006 and 2016 avian influenza outbreaks on consumer behaviour}

In order to obtain a more comprehensive picture about the impact of the avian influenza outbreak on consumer behaviour, we compared the data of the consumer surveys of 2006 (KASZA \& LAKNER, 2006) and 2016. Results are shown in Table 3.

Table 3. Changes in poultry meat consumption habits due to the avian influenza outbreaks $(2006,2016)$

\begin{tabular}{lrr}
\hline Changes in poultry meat consumption habits after the outbreaks & \multicolumn{2}{c}{ Distribution (\%) } \\
\cline { 2 - 3 } & 2006 & 2016 \\
\hline Abandoned or significantly reduced poultry meat consumption & 7.5 & 2.4 \\
Reduced poultry meat consumption & 16.5 & 9.2 \\
Unchanged poultry meat consumption & 74.7 & 87.4 \\
Increased poultry meat consumption & 1.3 & 1.0 \\
Total & 100.0 & 100.0 \\
\hline
\end{tabular}

Concerning the outbreak of $2006,7.5 \%$ of respondents abandoned or significantly reduced poultry meat consumption, whereas this ratio was only $2.4 \%$ in 2016 . There was also a significant difference in the proportion of respondents who reduced poultry meat consumption, as their share decreased with $7.3 \%$ by 2016. Simultaneously, the proportion of those who did not change their consumer habits compared with the 2006 results has increased with $12.6 \%$. Increased poultry meat consumption was negligible among respondents in both surveys with the proportion of $1.3 \%$ and $1.0 \%$. 


\section{Conclusions}

According to the results of our research, the highly pathogenic avian influenza outbreak of 2016 - as one of the most important food chain safety events of the recent years - significantly influenced the behaviour of lower educated and female consumers. The propensity of these consumers was higher to abandon or reduce poultry meat consumption due to the epidemic. Consequently, the most decisive factors of consumer risk perception proved to be education level and gender, and the effect of income level is also important. Comparison of the research data of 2006 and 2016 showed remarkable differences in regard of the impacts of the outbreaks on consumer behaviour. We have found that $25.3 \%$ of respondents changed poultry meat consumption patterns due to the outbreak of 2006, while in 2016 this ratio was only $12.6 \%$. Despite some limitations of the comparison (we were not able to filter out the possible impact of consumer price levels and the change of socio-economic variables between the two periods), it has been assumed that the proactive and responsive risk communication of public authorities effectively contributed to the mitigation of the public outrage in 2016. As another important conclusion, we might point out the importance of segmentation of the population when planning risk communication. People with lower education and income as well as female consumers tend to be more concerned about avian influenza outbreaks. In cases where the situation is firmly controlled, and thus food safety is not compromised, additional effort should be made to convince these subgroups of the safety of products. This activity could contribute to minimizing unnecessary economic losses.

\section{References}

BÁnÁti, D. \& LAKNer, Z. (2002): The food safety issue and the consumer behaviour in a transition economy: A case study of Hungary. Acta Alimentaria, 31, 21-36.

Brown, I., Mulatti, P., Smietanka, K., Staubach, C., Willeberg, P., Adlhoch, C., Candiani, D., Fabris, C., Zancanaro, G., Morgado, J. \& Verdonck, F. (2017): Avian influenza overview October 2016-August 2017. EFSA J., 15(10), 5018, 101 pages.

Byrnes, J.P., Miller, D.C. \& Schafer, W.D. (1999): Gender differences in risk taking: A meta-analysis. Psychol. Bull., 125, 367-383.

Charness, G. \& Gneezy, U. (2012): Strong evidence for gender differences in risk taking. J. Econ. Behav. Organ., 83, 50-58.

Fischioff, B., Slovic, P., Lichtenstein, S., Read, S. \& Combs, B. (1978): How safe is safe enough? A psychometric study of attitudes towards technological risks and benefits. Policy Sci., 9, 127-152.

Flynn, J., Slovic, P. \& Mertz, C.K. (1994): Gender, race, and perception of environmental health risks. Risk Anal., 14, 1101-1108.

FrEWER, L. (2004): The public and effective risk communication. Toxicol. Let., 149, 391-397.

HÁmori, G. (2001): A CHAID alapú döntési fák jellemzői. (Characteristics of CHAID-based decision trees). Statisztikai Szemle, 79, 703-710.

HCSO (2014): Population by gender (2001-). Source: http://www.ksh.hu/docs/hun/xstadat/xstadat_eves/i_ wdsd003a.html (last accessed: 21. April 2018)

HCSO (2016): Food Scales, 2014. Statistical Mirror. Available at: https://www.ksh.hu/docs/hun/xftp/stattukor/ elelmfogy/elelmfogy14.pdf (last accessed: 21. April 2018)

HCSO (2018): Consumer price index by products and services (STADAT). Hungarian Central Statistical Office, 2018

Kasza, Gy. \& Lakner, Z. (2006): The bird flu in mind of Hungarian consumers - lesson and experiences of a directquestion survey. Acta Agraria Kaposváriensis, 10, 229-235.

LACZAY, P. (2012): Élelmiszer-higiénia, élelmiszer-biztonság. Magyar Tudomány, 173, 4-10.

Lycett, S., Bodewes, R., Pohlmann, A., Banks, J., Banyai, K., Boni, M.F., Bouwstra, R., ... \& Kuiken, T. (2016): Role for migratory wild birds in the global spread of avian influenza H5N8. Science, 354, 213-217. 
Ózsvári, L., Tisóczki, R., Bartha, Á. \& HoRváth, M.K. (2017): The cost-benefit analysis of application of vitamin and mineral supplements in broiler chicken production. Hungarian Agricultural Engineering, 31, 45-51.

Siegrist, M. \& CVetкovich, G. (2000): Perception of hazards: The role of social trust and knowledge. Risk Anal., 20, $713-720$.

StimaK, M.W. \& Dietz, T. (2006): Personal values, beliefs, and ecological risk perception. Risk Anal., 26, 16891705.

Slovic, P. \& Peters, E. (2006): Risk perception and affect. Curr. Dir. Psychol. Sci., 15, 322-325.

Szeitz-Szabó, M. \& FarKas, J. (2004): National food safety program of Hungary. Acta Alimentaria, 33, 209-214.

Szeleczky, Z., Dản, Á., Ursu, K., Ivanics, É., Kiss, I., Erdélyi, K., ... \& BÁlint, Á. (2009): Four different sublineages of highly pathogenic avian influenza H5N1 introduced in Hungary in 2006-2007. Vet. Microbiol., 139, 24-33.

Verbeke, W., Frewer, L.J., Scholderer, J. \& De Brabander, H.F. (2007): Why consumers behave as they do with respect to food safety and risk information. Anal. Chim. Acta, 586, $2-7$.

WHO (2003): Influenza fact sheet. Fact sheet Nr. 211. World Health Organization. Available at: http://www.who.int/ mediacentre/factsheets/2003/fs211/en/

WHO (2009): Global influenza programme. Pandemic influenza preparedness and response: a WHO guidance document. World Health Organization. 64 pages.

WiLDAVSKY, A. \& DAKE, K. (1990): Theories of risk perception: Who fears what and why? Daedalus, 119(4), 41-60. 